\title{
Parametric Optimization for Friction Stir Welding of Al6061 Alloy using Taguchi Technique
}

\author{
Lingam Satyavinod ${ }^{1}$, R Harikishore ${ }^{2}$ \\ ${ }^{1}$ Student, Department of Mechanical Engineering, DNREng College, Bhimavaram, Andhra Pradesh, India \\ ${ }^{2}$ Assistant Professor, Department of Mechanical Engineering, DNREng. College, Bhimavaram, Andhra Pradesh, India
}

\begin{abstract}
Nine welded joints of 6061 aluminium alloy were made on friction stir welding set up with the L9 orthogonal array of Taguchi s methodology of three input parameters with three different levels. The processing parameters such as tool rotational speed, transverse feed and tilt angle are taken into account. Experiments or tests such as tensile test, hardness test and surface roughness tests were conducted to evaluate the mechanical properties such as tensile strength, hardness value and surface roughness values. At last, optimum values of corresponding tests are determined. The results were confirmed by further experiments.
\end{abstract}

Keywords: Friction Stir Welding (FSW), Al 6061, Tensile Strength, Hardness, Surface Roughness, and Taguchi Technique

\section{Introduction.}

Traditional fusion welding is not suitable for the welding of soft materials. Friction stir welding is the best technique to full fill the requirements of welding of soft materials like Al, $\mathrm{Ti}$, and Steel etc.Friction Stir Welding is a Solid State Welding process in which source of welding is Friction. Friction will be generated by the non consumable tool on the work piece material. Initially the material will be melted below the melting point temperature and then it converts into plastic state at the welding location by applying amount of axial force. There is no usage of additional filler material here. This technique can be used for the welding of similar or dissimilar materials. Friction Stir welding is a Green welding technology and Non Toxic.Friction Stir Welding is invented by The Welding Institute (TWI) of the United Kingdom in 1991. This fabrication technique plays a vital role in the NASA and other Aircraft Industries.

\subsection{Principle of Friction stir Welding Process}

The Non consumable tool consists of shoulder and a pin which will be fixed in a tool holder and rotated with certain rpm. The Aluminium square mating edges are fixed with the special clamping fixture to avoid the moment of the work piece during in operation or made to be at rest. Now the rotating tool is plunged into the work piece until the length of the pin. So here shoulder is making contact with the top surface of the work piece. When the tool is rotating about its longitudinal axis,(with or without inclination)stirring action will be made so the material will undergo softened plastic deformation and tool is transverse in the desired direction so the material is intermixed along the desired direction and weld will be formed under the below the melting point temperature. There is no addition of filler material in this process.

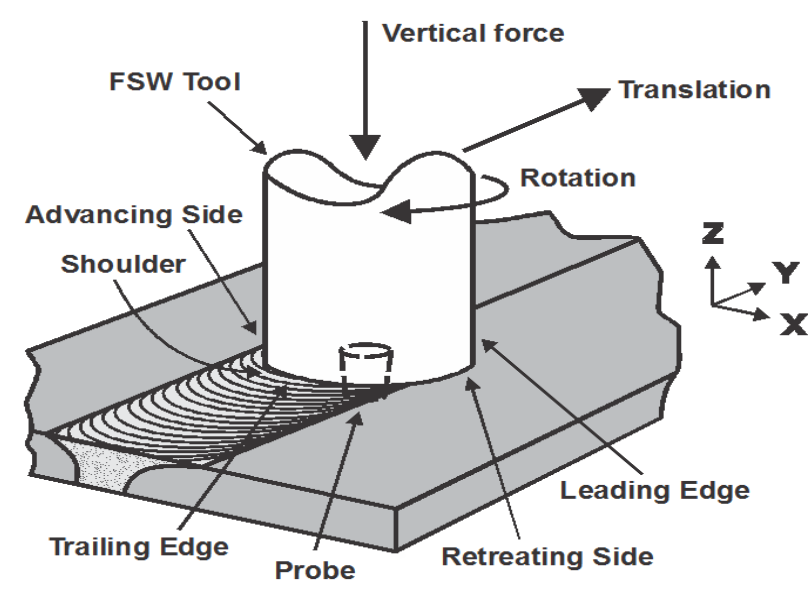

Schematic diagram of Friction stir welding Technique

\subsection{Need}

Since the invention of friction stir welding, it plays a vital role in the industries and has wide range of applications in variety of industries. It is selected as a most appropriate one on behalf of its nature of higher efficiency at higher mass production. This welding gives very characteristic values, uniformity of weld properties. Some of the advantages are no need of external source of energy, welding will be takes place at much below melting point of the work piece material, the wear and tear of the tool is less or tool life will be good. These are some additional advantages of friction stir welding made it as a unique welding process. The welding is possible with very low cost.

\section{Methodology and Experimental Set Up}

\section{Methodology}

The nine welded joints were made on friction stir welding setup with three different levels of processing parameters like Spindle Speed (rpm), Translational feed $(\mathrm{mm} / \mathrm{min})$ and Tilt Angle (in degrees). The testing will be followed to determine the optimum characteristic values of tensile strength, hardness and surface roughness. 


\section{International Journal of Science and Research (IJSR) \\ ISSN (Online): 2319-7064}

Index Copernicus Value (2015): 78.96 | Impact Factor (2015): 6.391

Table 1: Shows Processing Parameters and their levels

\begin{tabular}{|c|c|c|c|c|c|}
\hline S.No & Parameter & \multirow{2}{*}{ Unit } & \multicolumn{3}{|c|}{ Level } \\
\cline { 4 - 6 } & & & 1 & 2 & 3 \\
\hline 1 & Spindle speed & Rpm & 900 & 1000 & 1100 \\
\hline 2 & Transverse feed & Mm/min & 42 & 55 & 68 \\
\hline 3 & Tilt angle & Degree & 0 & 1 & 2 \\
\hline
\end{tabular}

Table 2: Shows Taguchi L9 orthogonal array

\begin{tabular}{|c|c|c|c|}
\hline \multirow{2}{*}{ S.NO } & \multicolumn{3}{|c|}{ Processing Parameters } \\
\cline { 2 - 4 } & Spindle speed & Transverse feed & Tilt angle \\
\hline 1 & 900 & 42 & 0 \\
\hline 2 & 900 & 55 & 1 \\
\hline 3 & 900 & 68 & 2 \\
\hline 4 & 1000 & 42 & 1 \\
\hline 5 & 1000 & 55 & 2 \\
\hline 6 & 1000 & 68 & 0 \\
\hline 7 & 1100 & 42 & 2 \\
\hline 8 & 1100 & 55 & 0 \\
\hline 9 & 1100 & 68 & 1 \\
\hline
\end{tabular}

The working ranges are finalised by the previous research work and conducting trail run.L9 orthogonal array of Taguchi is applied in the present study.

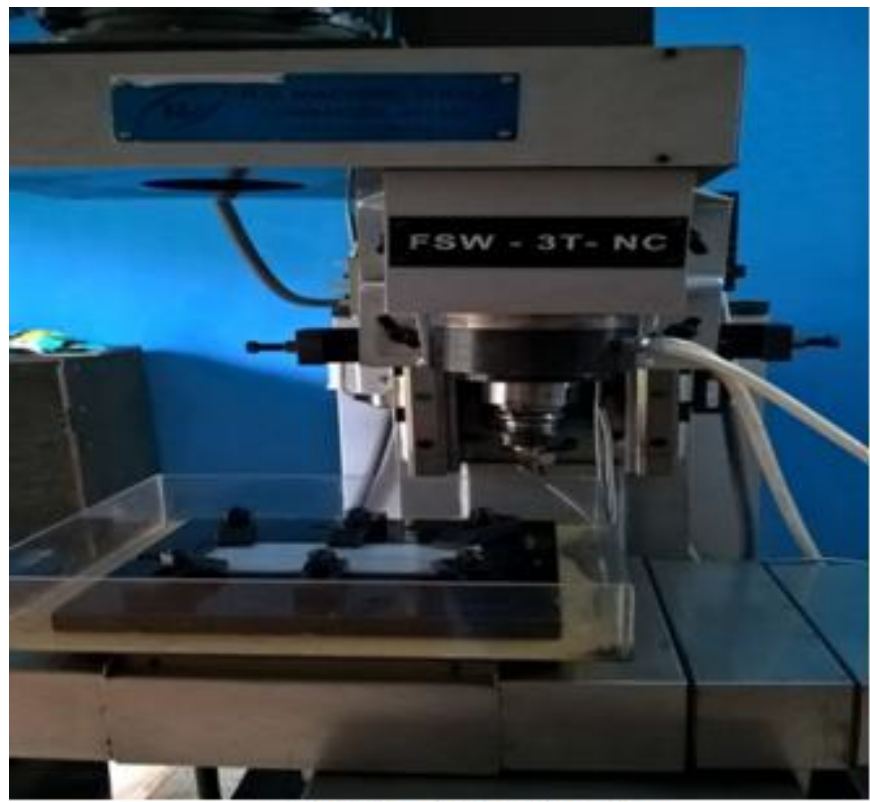

Friction stirs welding setup
Work piece Material and TOOL

The material under the investigation found that $\mathrm{Al} 6061$ has excellent joining characteristics and wide range of applications. So Al 6061 is taken with dimensions $125 \times 60 \times 6$ (in $\mathrm{mm}$ ).

\section{Nominal chemical composition of 6061}

\begin{tabular}{|l|c|c|c|c|c|c|c|c|c|}
\hline Element & $\mathrm{Si}$ & $\mathrm{Fe}$ & $\mathrm{Cu}$ & $\mathrm{Mn}$ & $\mathrm{Mg}$ & $\mathrm{Cr}$ & $\mathrm{Zi}$ & $\mathrm{Ti}$ & $\mathrm{Al}$ \\
\hline $\mathrm{Wt}(\%)$ & 0.59 & 0.38 & 0.26 & 0.03 & 0.96 & 0.25 & 0.02 & 0.04 & Balance \\
\hline
\end{tabular}

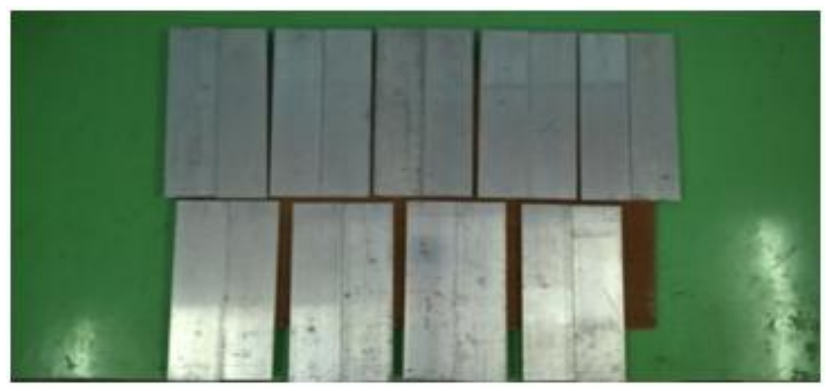

Al specimens to be welded

\section{Experimental Setup}

Nine Square butt joints were made on Friction Stir welding equipment setup. The Friction stir welding setup is manufactured by R.V. MACHINE TOOLS, Coimbatore.

\section{Results and Discussions}

The Tensile Test, Surface Roughness Test and Hardness tests are conducted to evaluate the mechanical properties of the welded joints and corresponding $\mathrm{S} / \mathrm{N}$ Ratios, Mean values, Main effects plots for means and $\mathrm{S} / \mathrm{N}$ ratios are calculated with the help of Minitab17. These values will give a clear idea to determine the best quality of weld.

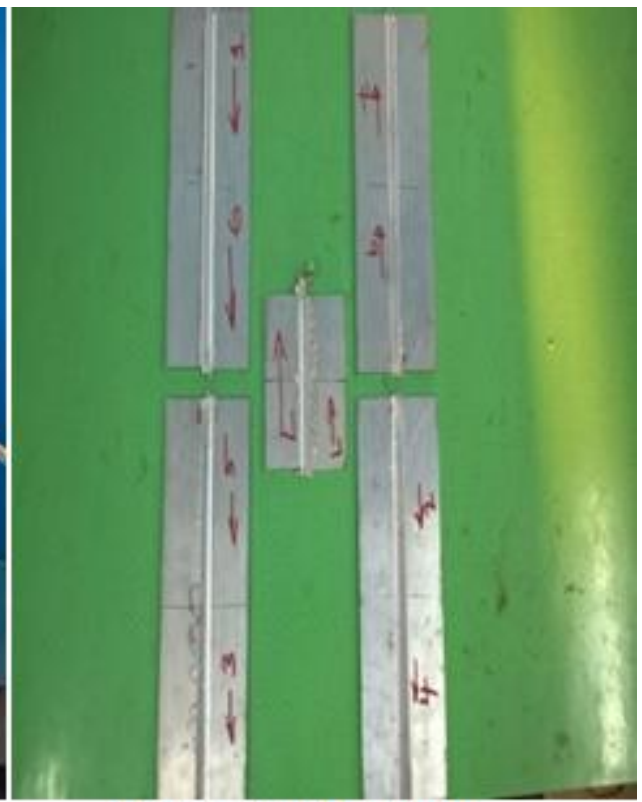

Al6061 welded specimens

\section{Tensile test}

Tensile test is used to determine the tensile strength of the welded portion of the friction stir weld specimen. Wire cutting EDM machine is used to cut tensile specimens from the Nine FSW welded joints individually. The below figures will show the tensile specimens before the test and after the test. 


\section{International Journal of Science and Research (IJSR) \\ ISSN (Online): 2319-7064}

Index Copernicus Value (2015): 78.96 | Impact Factor (2015): 6.391

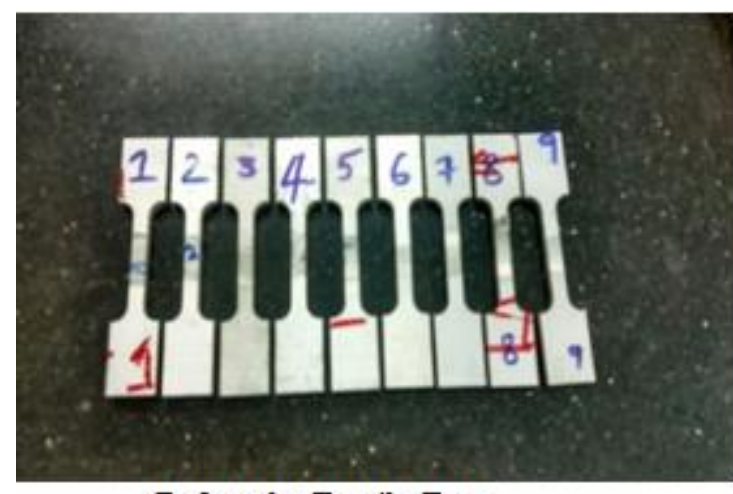

Before the Tensile Test

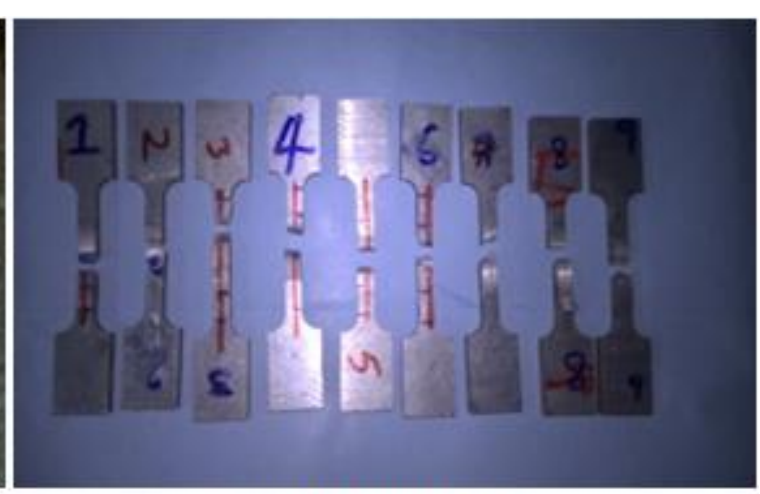

After the tensile Test

\section{Tensile Strength Analysis}

Table: Process parameters and experimental results

\begin{tabular}{|c|c|c|c|c|c|c|c|}
\hline S no & \multicolumn{3}{|c|}{ Process Parameters } & \multicolumn{4}{c|}{ Experimental Results } \\
\hline $\begin{array}{c}\text { Specimen } \\
\text { number }\end{array}$ & $\begin{array}{c}\text { Spindle } \\
\text { Speed (rpm) }\end{array}$ & $\begin{array}{c}\text { Translational } \\
\text { feed(mm/min) }\end{array}$ & $\begin{array}{c}\text { Tilt Angle } \\
\text { (Degrees) }\end{array}$ & $\begin{array}{c}\text { Temperature } \\
\text { (in centi } \\
\text { grade) }\end{array}$ & $\begin{array}{c}\text { Tensile } \\
\text { strength }\end{array}$ & $\begin{array}{c}\text { Percentage } \\
\text { elongation }\end{array}$ & S/N Ratios \\
\hline 1 & 900 & 42 & 0 & 116 & 100.750 & 8.44 & 40.0649 \\
\hline 2 & 900 & 55 & 1 & 105 & 89.166 & 9.80 & 39.0040 \\
\hline 3 & 900 & 68 & 2 & 147 & 134.536 & 22.80 & 44.1403 \\
\hline 4 & 1000 & 42 & 1 & 127 & 92.405 & 6.80 & 39.3139 \\
\hline 5 & 1000 & 55 & 2 & 195 & 170.633 & 16.36 & 44.6413 \\
\hline 6 & 1000 & 68 & 0 & 143 & 133.129 & 14.36 & 42.4855 \\
\hline 7 & 1100 & 42 & 2 & 135 & 95.041 & 9.12 & 39.5582 \\
\hline 8 & 1100 & 55 & 0 & 120 & 66.071 & 4.72 & 36.4002 \\
\hline 9 & 1100 & 68 & 1 & 117 & 82.761 & 5.64 & 38.3565 \\
\hline
\end{tabular}

The above table represents the results of the tensile tests conducted on Friction stir weld tensile specimens of $\mathrm{Al}$ 6061. Through the usage of Minitab-17, the $\mathrm{S} / \mathrm{N}$ ratio values are also evaluated. The $\mathrm{S} / \mathrm{N}$ ratio values are used to determine the quality of weld. That means the weld which is having high $\mathrm{S} / \mathrm{N}$ ratio value means it is good quality of a weld. The Minitab-17 is also used to plot the graphs like Main Effects of plot for SN ratios. The ultimate tensile test is 170.633, determined at specimen weld no.5, and its parameters are $1000 \mathrm{rpm}, 55 \mathrm{~mm} / \mathrm{min}$ and 1 degree.

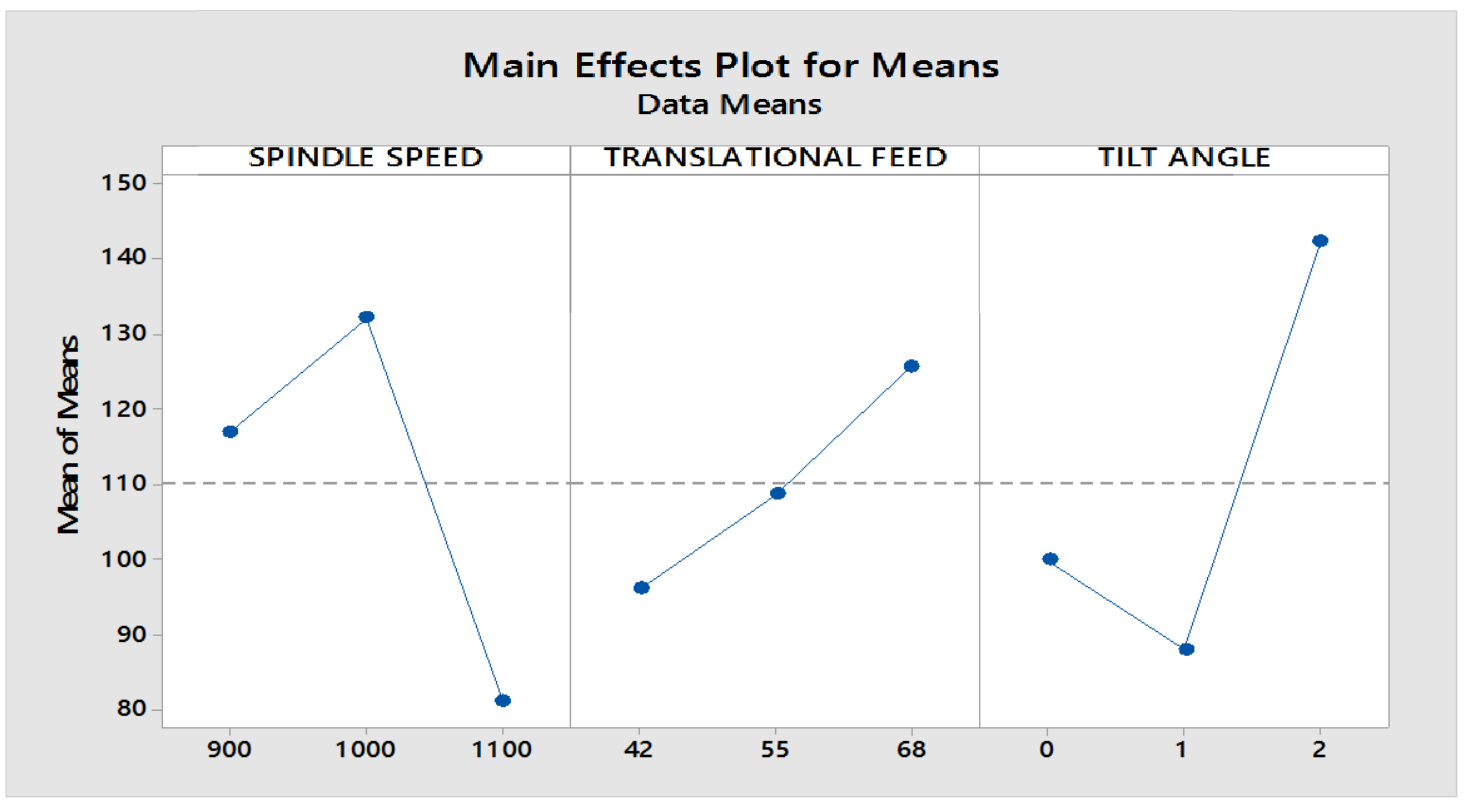

Volume 6 Issue 1, January 2017 


\section{International Journal of Science and Research (IJSR) \\ ISSN (Online): 2319-7064}

Index Copernicus Value (2015): 78.96 | Impact Factor (2015): 6.391

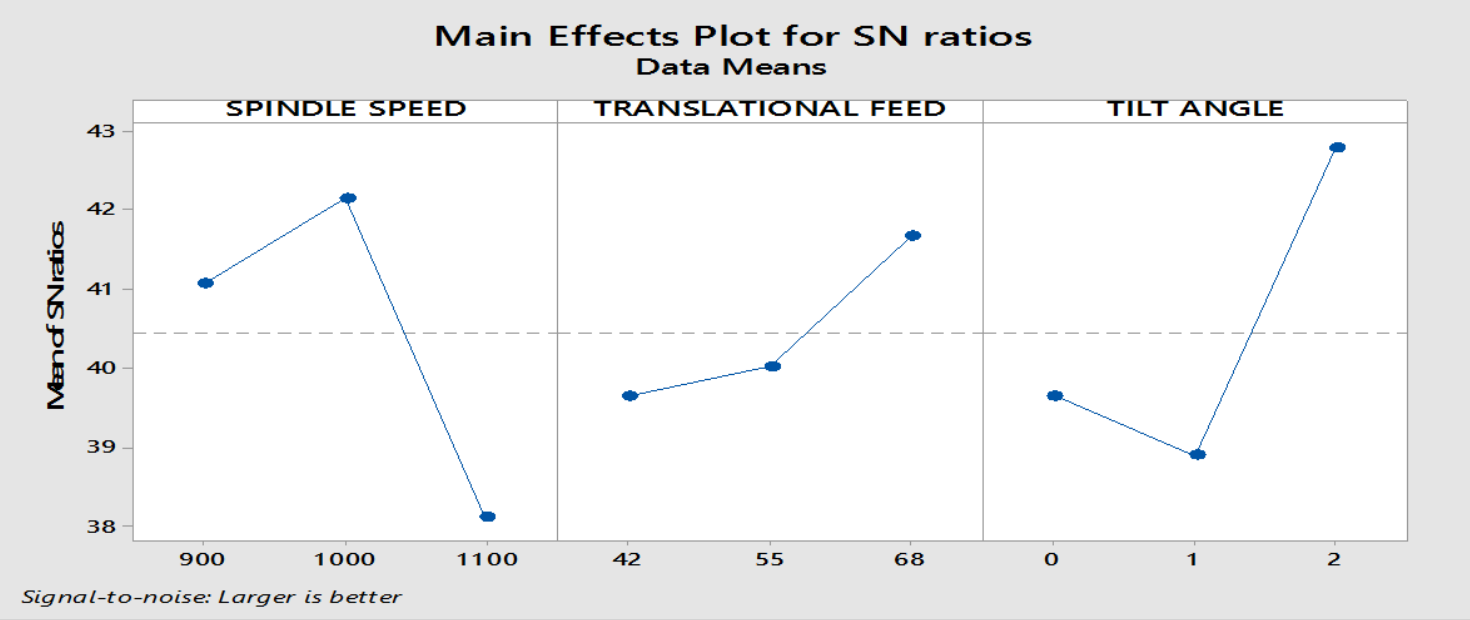

Response Table for Means

\begin{tabular}{|c|c|c|c|}
\hline Level & Spindle speed & Translational Feed & Tilt angle \\
\hline 1 & 117.00 & 96.07 & 99.98 \\
\hline 2 & 132.06 & 108.62 & 88.11 \\
\hline 3 & 81.29 & 125.65 & 142.25 \\
\hline Delta & 50.76 & 29.59 & 54.14 \\
\hline Rank & 1 & 3 & 2 \\
\hline
\end{tabular}

Table for Signal to Noise Ratios

\section{Hardness Analysis}

The below table represents the Hardness values of Nine Friction stir welded joints and corresponding S/N Ratios,

\begin{tabular}{|c|c|c|c|}
\hline Level & Spindle speed & Translational Feed & Tilt angle \\
\hline 1 & 41.05 & 39.65 & 39.65 \\
\hline 2 & 42.15 & 40.02 & 38.89 \\
\hline 3 & 38.10 & 41.66 & 42.78 \\
\hline Delta & 4.04 & 2.02 & 3.89 \\
\hline Rank & 1 & 3 & 2 \\
\hline
\end{tabular}

Mean values. The hardness test was conducted on Rockwell hardness testing machine.

\begin{tabular}{|c|c|c|c|c|c|c|}
\hline S no & \multicolumn{3}{|c|}{ Process Parameters } & \multicolumn{3}{c|}{ Experimental Results } \\
\hline $\begin{array}{c}\text { Specimen } \\
\text { number }\end{array}$ & Spindle Speed (rpm) & $\begin{array}{c}\text { Translational feed } \\
(\mathrm{mm} / \text { min) }\end{array}$ & Tilt Angle & $\begin{array}{c}\text { Temperature } \\
\text { (in centi grade) }\end{array}$ & Hardness Number (HBN) & S/N Ratios \\
\hline 1 & 900 & 42 & 0 & 116 & 17 & 24.6090 \\
\hline 2 & 900 & 55 & 1 & 105 & 23.5 & 27.4214 \\
\hline 3 & 900 & 68 & 2 & 147 & 13.5 & 22.6067 \\
\hline 4 & 1000 & 42 & 1 & 127 & 11.5 & 21.2140 \\
\hline 5 & 1000 & 55 & 2 & 195 & 11 & 20.8279 \\
\hline 6 & 1000 & 68 & 0 & 143 & 18 & 25.1055 \\
\hline 7 & 1100 & 42 & 2 & 135 & 1.5 & 21.2140 \\
\hline 8 & 1100 & 55 & 0 & 120 & 13.5 & 22.6067 \\
\hline 9 & 1100 & 68 & 1 & 117 & 23 & 27.2346 \\
\hline
\end{tabular}

The Best Hardness value is determined at specimen weld no. 2 is $23.5 \mathrm{HBN}$, and its parameters are $900 \mathrm{rpm}, 55$ $\mathrm{mm} / \mathrm{min}$ and 1 degree. The $\mathrm{S} / \mathrm{N}$ ratio values are calculated with the help of MiniTab-17 and also the Main Effects plot for $\mathrm{S} / \mathrm{N}$ ratios can be dawned.

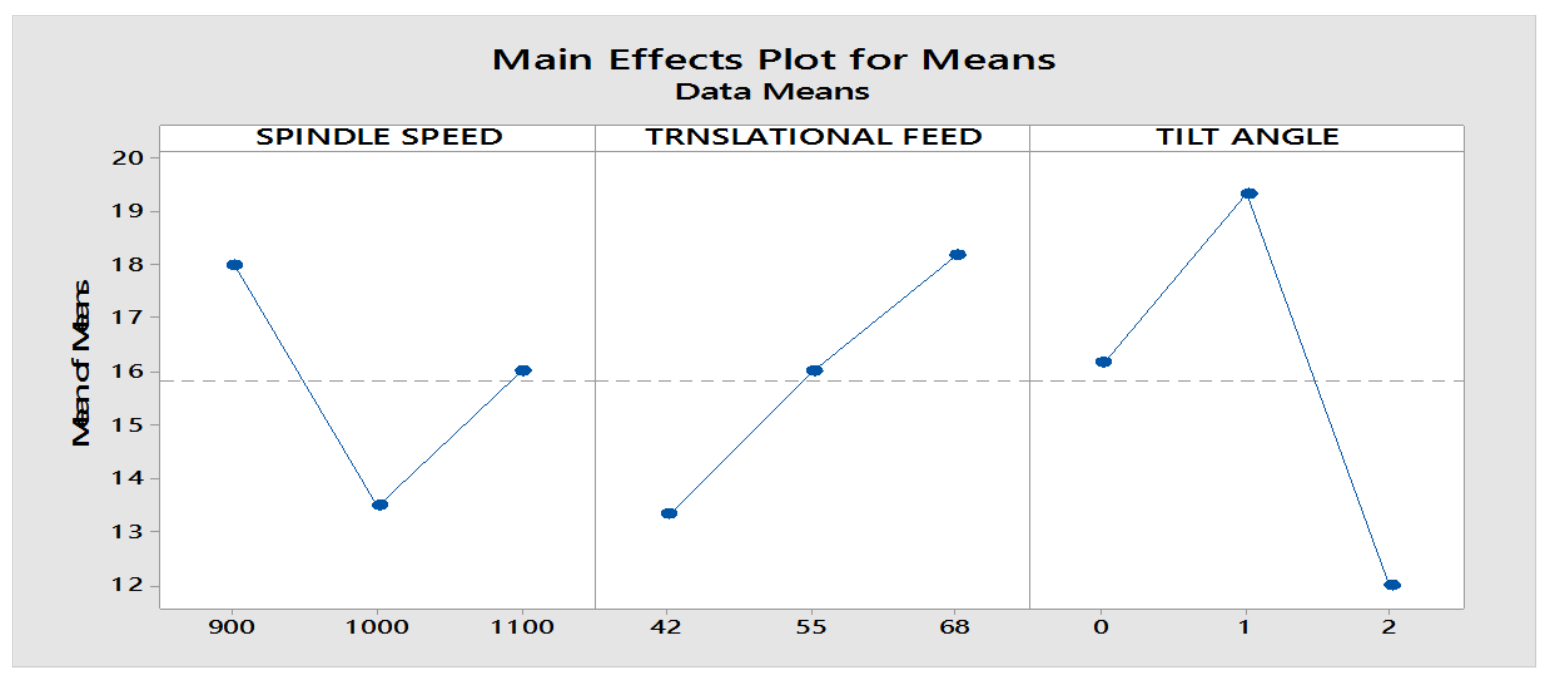

Volume 6 Issue 1, January 2017

www.ijsr.net

Licensed Under Creative Commons Attribution CC BY 


\section{International Journal of Science and Research (IJSR) \\ ISSN (Online): 2319-7064}

Index Copernicus Value (2015): 78.96 | Impact Factor (2015): 6.391

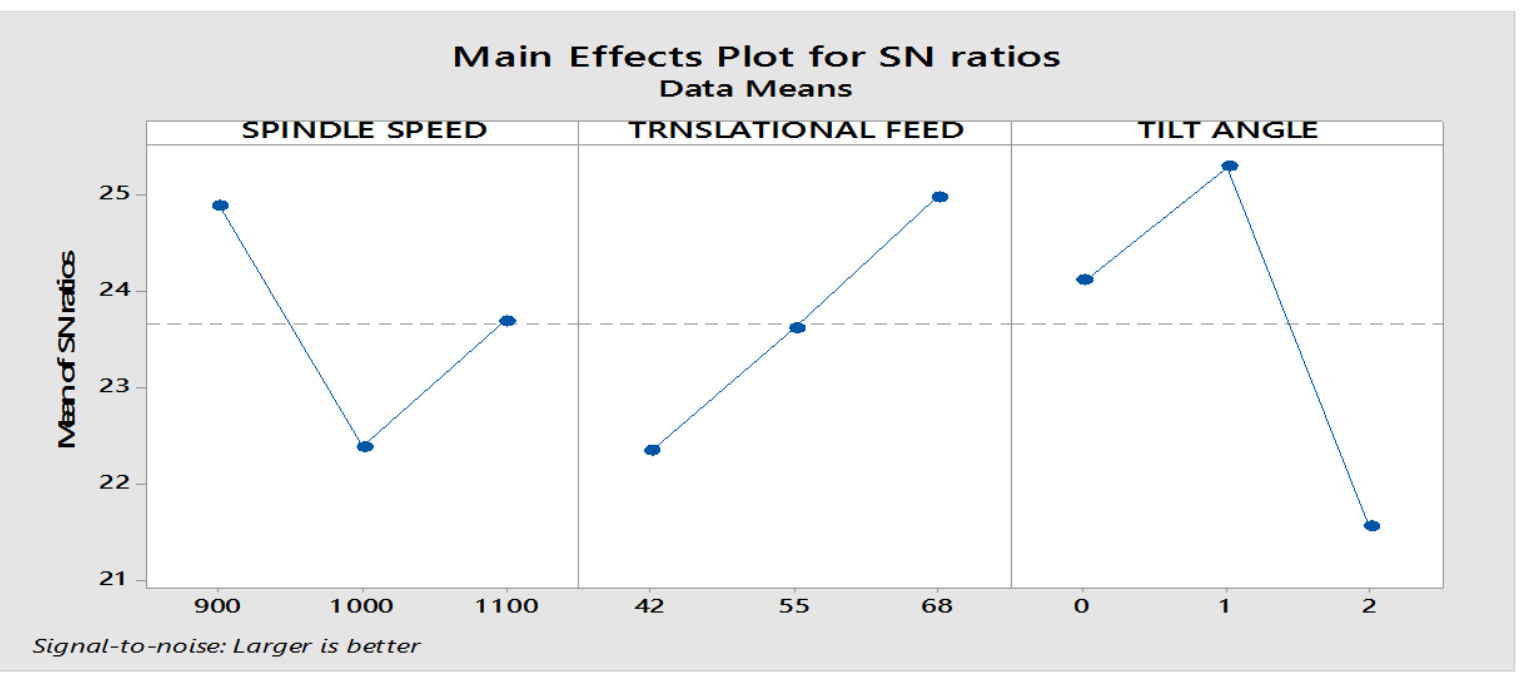

Response Table for Means

\begin{tabular}{|c|c|c|c|}
\hline Level & Spindle speed & Translational Feed & Tilt angle \\
\hline 1 & 18.00 & 13.33 & 16.17 \\
\hline 2 & 13.50 & 16.00 & 19.23 \\
\hline 3 & 16.00 & 18.17 & 12.00 \\
\hline Delta & 4.50 & 4.83 & 7.33 \\
\hline Rank & 3 & 2 & 1 \\
\hline
\end{tabular}

Table for Signal to Noise Ratios

\begin{tabular}{|c|c|c|c|}
\hline Level & Spindle speed & Translational Feed & Tilt angle \\
\hline 1 & 24.88 & 22.35 & 24.11 \\
\hline 2 & 22.38 & 23.62 & 25.29 \\
\hline 3 & 23.69 & 24.98 & 21.55 \\
\hline Delta & 2.50 & 2.64 & 3.74 \\
\hline Rank & 3 & 2 & 1 \\
\hline
\end{tabular}

\section{Surface Roughness Test}

Surface Roughness test is conducted to find the surface roughness values at the friction stir welded joints. This test reveals the Surface finish or the smoothness of the friction stir weld joints.

\begin{tabular}{|c|c|c|c|c|c|c|}
\hline $\begin{array}{c}\text { Specimen } \\
\text { number }\end{array}$ & $\begin{array}{c}\text { Spindle } \\
\text { Speed }(\mathrm{rpm})\end{array}$ & $\begin{array}{c}\text { Translational feed } \\
(\mathrm{mm} / \mathrm{min})\end{array}$ & $\begin{array}{c}\text { Tilt Angle } \\
\text { (Degrees) }\end{array}$ & $\begin{array}{c}\text { Temperature } \\
\text { (in centi grade) }\end{array}$ & Surface roughness & SNRA1 \\
\hline 1 & 900 & 42 & 0 & 116 & 3.272 & -10.2963 \\
\hline 2 & 900 & 55 & 1 & 105 & 1.2533 & -1.9611 \\
\hline 3 & 900 & 68 & 2 & 147 & 2.288 & -7.1891 \\
\hline 4 & 1000 & 42 & 1 & 127 & 1.036 & -0.3072 \\
\hline 5 & 1000 & 55 & 2 & 195 & 1.0476 & -0.4039 \\
\hline 6 & 1000 & 68 & 0 & 143 & 3.245 & -10.2243 \\
\hline 7 & 1100 & 42 & 2 & 135 & 0.771 & 2.2589 \\
\hline 8 & 1100 & 55 & 0 & 120 & 1.606 & -4.1149 \\
\hline 9 & 1100 & 68 & 1 & 117 & 0.529 & 5.5309 \\
\hline
\end{tabular}

The ultimate surface roughness value is determined at weld specimen no.7 is 0.771 , and corresponding processing parameters are $1100 \mathrm{rpm}, 42 \mathrm{~mm} / \mathrm{min}$ and 0 degree. The $\mathrm{S} / \mathrm{N}$ ratio values are calculated with the help of MiniTab-17 and also the Main Effects plot for $\mathrm{S} / \mathrm{N}$ ratios can be dawned.
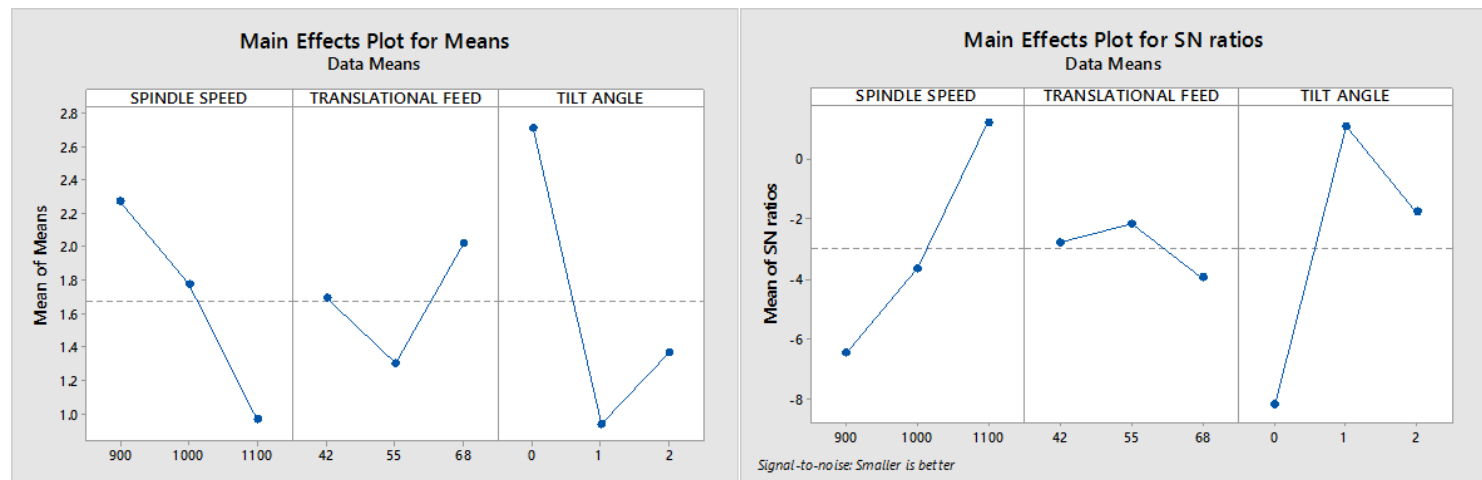

Volume 6 Issue 1, January 2017 www.ijsr.net 


\section{International Journal of Science and Research (IJSR) \\ ISSN (Online): 2319-7064}

Index Copernicus Value (2015): 78.96 | Impact Factor (2015): 6.391

Response Table for Means

\begin{tabular}{|l|l|l|l|}
\hline Level & Spindle speed & Translational Feed & Tilt angle \\
\hline 1 & 2.2711 & 1.6930 & 2.7077 \\
\hline 2 & 1.7762 & 1.3023 & 0.9394 \\
\hline 3 & 0.9687 & 2.0207 & 1.3689 \\
\hline Delta & 1.3024 & 0.7184 & 1.7682 \\
\hline Rank & 2 & 3 & 1 \\
\hline
\end{tabular}

Table for Signal to Noise Ratios

\begin{tabular}{|l|l|l|l|}
\hline Level & Spindle speed & Translational Feed & Tilt angle \\
\hline 1 & -6.482 & -2.782 & -8.212 \\
\hline 2 & -3.645 & -2.160 & 1.088 \\
\hline 3 & 1.225 & -3.961 & -1.778 \\
\hline Delta & 7.707 & 1.801 & 9.229 \\
\hline Rank & 2 & 3 & 1 \\
\hline
\end{tabular}

\section{Conclusion}

In the present study, the butt joint configuration of 6061aluminium alloy was successfully prepared on Friction stir welding equipment. The weld specimens were tested for tensile strength, hardness and surface roughness at their weld postion.L9 array of Taguchi technique was performed in the study.

The optimum tensile strength is observed at spindle rotational speed $1000 \mathrm{rpm}$, transverse feed $55 \mathrm{~mm} / \mathrm{min}$, and tilt angle 1degree.

The optimum hardness value is observed at spindle speed $900 \mathrm{rpm}$, transverse feed $55 \mathrm{~mm} / \mathrm{min}$, tilt angle 1 degree. The optimum Surface roughness value is observed at spindle rotational speed $1100 \mathrm{rpm}$, transverse feed $42 \mathrm{~mm} / \mathrm{min}$, tilt angle 0 degree.

\section{References}

[1] Mishra, Z.Y.Ma, "Friction stir welding and processing ", Elsevier, 2005.

[2] Omar s. Salih, Hengan Ou, W.Sun, D.G.McCartney,"A review of friction stir welding of aluminum matrix composites", Elsevier, 2015.

[3] Raj Kumar V, Venkateshkanan , " Studies on effect of tool design and welding parameters on the friction stir welding of dissimilar aluminium alloys AA 5052AA6061, Elsevier,2015.

[4] T. Deb Roy and H.K.D.H. Bhadeshia "Friction stir welding of dissimilar alloys- a Perspective, 2010, science and technology of welding and Joining.

[5] Heena SharmaKamleshBhatt,KrunalShahcandUnnatiJoshid ,“ Experimental Analysis of friction stir welding of Dissimilar alloys AA 6061 and Mg AZ31 using circular Butt joint geometry", Elsevier, 2016.

[6] G, Ram Babu (2015), "optimization of friction stir welding parameters for improved corrosion resistance of AA2219 Aluminium alloy joints.

[7] SuyashTiwari, H.Chelladurai, "Parametric Analysis of friction stir welding", All India Manufacturing Technology, Design and research conference,2014.

[8] Ram, Janender Kumar , “ parametric optimization for friction stir welding of Al 6063 Alloy using Taguchi Technique ", International journal of latest trends in Engineering and Technology(IJLET),2016.

[9] Edwin Santhkumar, 2016, "Experimental Analysis of process parameters in friction stir welding using Aluminium 2024 and $\mathrm{Al} 7075$. 